\section{Pollen Viability of Selected Diploid Watermelon Pollenizer Cultivars}

\author{
Josh H. Freeman ${ }^{1}$ \\ Department of Horticulture, Virginia Polytechnic Institute and State \\ University, Eastern Shore Agricultural Research and Extension Center, \\ Painter, VA 23420
}

Stephen M. Olson

Department of Horticultural Sciences, University of Florida, North Florida Research and Education Center, 155 Research Road, Quincy, FL 32351

Eileen A. Kabelka

Department of Horticultural Sciences, University of Florida, Box 110690 Fifield Hall, Gainesville, FL 32611

Additional index words. Citrullus lanatus, Cucurbitaceae, seedless, in-row pollenizer, triploid, special pollenizer

\begin{abstract}
In the Spring and Fall 2006, the pollen viability of four diploid watermelon pollenizers was evaluated in Quincy, FL. Triploid watermelon plants [Citrullus lanatus (Thunb.) Matsum. \& Nakai.] do not produce sufficient viable pollen to pollenize themselves and a diploid cultivar must be interplanted as a pollen source. Recent studies have illustrated differences in triploid watermelon yields as a result of the pollenizer cultivar used. The viability of the pollen produced by pollenizer cultivars may greatly influence the fruit set and fruit quality in the triploid watermelon crop. Pollen samples were taken from 'Companion', 'Jenny', 'Mickylee', and 'SP-1' and were stained to determine their viability. There were no significant differences in pollen viability among cultivars and all cultivars had high average viability. Pollen viability was never lower than $\mathbf{9 5 \%}$ for any cultivar. This study indicates that pollen viability of the cultivars evaluated should not influence their effectiveness as pollenizers.
\end{abstract}

Seedless watermelons account for $78 \%$ of the watermelons sold in the United States (U.S. Department of Agriculture, 2006). Triploid watermelon plants do not produce sufficient viable pollen to pollenize themselves and a diploid cultivar must be interplanted as a pollenizer (pollen source) (Maynard and Elmstrom, 1992). Growers have traditionally planted every fourth or fifth row in the field with a diploid cultivar and harvested both seeded and seedless watermelons.

Diploid cultivars have recently been developed to be planted in-row as pollen sources between triploid plants without altering the triploid spacing's or affecting marketable yield. Freeman et al. (2007) observed significant differences in the performance of in-row pollenizers based on seedless watermelon yield. Triploid plants pollenized by 'Companion' yielded less than those pollenized by 'Jenny', 'Patron', 'SP-1', and 'Sidekick'. Fiacchino and Walters (2003) demonstrated that 'Crimson Sweet' was a more effective pollenizer than 'Fiesta' based on greater seedless watermelon yields and less incidence of hollowheart. Studies on 'Crimson Sweet' and 'Fiesta' by Stanghellini

Received for publication 11 July 2007. Accepted for publication 7 Aug. 2007.

${ }^{1}$ To whom reprint requests should be addressed; e-mail joshfree@vt.edu and Schultheis (2005) illustrated that there were no statistical differences in pollen production between the two cultivars. This suggests that there may be other factors that contribute to a pollenizer's performance.

Pollen viability could be a determining factor in the performance of watermelon pollenizers. Pollen flow from a pollenizer would be of little value if the viability was low, because pollen tube growth and ovule fertilization are necessary for seedless fruit maturation (Maynard and Elmstrom, 1992; Rhodes et al., 1997; Robinson and DeckerWalters, 1997). Poor pollination in watermelon can affect fruit shape and thus its marketability and may be a contributing factor to the physiological disorder termed hollowheart (Fiacchino and Walters, 2003; Maynard, 1992). Research in other plant families has shown that there can be substantial differences in pollen viability within a species and between closely related species (Fortescue and Turner, 2004; Lavi et al., 1996; Nikkanen et al., 2000; Parzies et al., 2005). Fortescue and Turner (2004) reported significant differences in pollen viability between cultivars of banana (Musa acuminata Colla). Studies conducted in mandarin orange (Citrus reticulata Blanco) have shown that pollen source can affect yield and quality characteristics such as soluble solids (Vithanage, 1991; Wallace and Lee, 1999). Differences in pollen viability have been reported in rabbiteye blueberry; how- ever, all cultivars examined had high average viability and probably had no effect on reproductive success (Brevis et al., 2006).

Cultivars used in this study were chosen because previous research has illustrated differences in their performance and pollen viability may be a contributing factor (Freeman et al., 2007). The objective of this research was to determine the pollen viability of four diploid watermelon pollenizer cultivars.

\section{Materials and Methods}

On 3 Apr. and 1 Aug. 2006, 4-week-old watermelon seedlings were transplanted into raised beds covered with black polyethylene mulch in the spring and white on black polyethylene mulch in the fall. Experiments were performed at the North Florida Research and Education Center (NFREC) in Quincy, FL. Soil type at NFREC is Norfolk loamy sand (fine-loamy, kaolinitic, thermic Typic Kandiudults). The experimental design was a randomized complete block with four replications. The pollen viability of four diploid pollenizer cultivars, 'Companion', 'Jenny', 'Mickylee', and 'SP-1', was determined. Experimental plots were $4.57 \mathrm{~m}$ long with in-row spacing of $0.91 \mathrm{~m}$ and betweenrow spacing of $2.43 \mathrm{~m}$. Three pollenizer seedlings were planted at even spacing in the center of each plot. Fertilization, irrigation, and pesticide application practices were followed using recommendations provided by the University of Florida Institute of Food and Agricultural Sciences (Olson et al., 2006).

In the spring, sampling was initiated on 17 May with additional pollen samples taken on 24 May and 31 May. For the fall, sampling was initiated on $31 \mathrm{Aug}$. with other pollen samples taken on 7 Sept. and 14 Sept. The sampling period was scheduled to coincide with the fruit-setting period of adjacent triploid plants transplanted on the same date.

On the sampling dates, watermelon flowers were removed from the plant before the flowers opened. This was to ensure that pollinators would not remove pollen and an adequate supply of pollen would be available for analysis. Three staminate flowers were removed from each plot and placed into plastic cups and covered to exclude pollinators. Flowers were taken to the laboratory and

Table 1. Analysis of variance for pollen viability of watermelon pollenizer cultivars tested in Spring and Fall 2006 at Quincy, FL.

\begin{tabular}{lccc}
\hline Source & $d f$ & MS & $P$ value \\
\hline \multicolumn{3}{c}{ Spring } \\
Replication & 3 & 0.00410 & 0.410 \\
Sampling date & 2 & 0.02827 & 0.003 \\
Cultivar & 3 & 0.00856 & 0.124 \\
Date*cultivar & 6 & 0.00281 & 0.669 \\
Error & 33 & 0.00415 & \\
& Fall & & \\
Replication & 3 & 0.00290 & 0.408 \\
Sampling date & 2 & 0.00302 & 0.367 \\
Cultivar & 3 & 0.00281 & 0.422 \\
Date*cultivar & 6 & 0.00257 & 0.519 \\
Error & 33 & 0.00292 & \\
\hline & & &
\end{tabular}

HortScience Vol. 43(1) February 2008 
Table 2. Pollen viability of four diploid watermelon pollenizer cultivars at Quincy, FL, during the Spring and Fall 2006.

\begin{tabular}{lllllll}
\hline & \multicolumn{5}{c}{ Pollen viability } \\
\cline { 2 - 6 } Pollenizer cultivar & $17 \mathrm{May}$ & $24 \mathrm{May}$ & 31 May & 31 Aug. & 7 Sept. & 14 Sept. \\
\hline Mickylee & $97.8 \mathrm{NS}^{\mathrm{z}}$ & $98.0 \mathrm{NS}^{\mathrm{z}}$ & $98.7 \mathrm{NS}^{\mathrm{z}}$ & $97.4 \mathrm{Ns}^{\mathrm{z}}$ & $98.2 \mathrm{NS}^{\mathrm{z}}$ & $97.8 \mathrm{NS}^{\mathrm{z}}$ \\
Companion & 97.4 & 97.2 & 99.2 & 97.6 & 98.1 & 98.8 \\
Jenny & 97.3 & 97.2 & 98.3 & 97.8 & 97.7 & 97.0 \\
SP-1 & 97.2 & 95.5 & 98.1 & 97.9 & 98.7 & 97.6 \\
Date means & $97.4 \mathrm{~b}^{\mathrm{y}}$ & $97.0 \mathrm{~b}$ & $98.6 \mathrm{a}$ & $97.7 \mathrm{NS}^{\mathrm{y}}$ & 98.2 & 97.8 \\
\hline
\end{tabular}

${ }^{\mathrm{z}} P=0.05$; means are compared within the same column.

${ }^{\mathrm{y}} P=0.05$; means from the same season are compared within the row.

${ }^{\mathrm{N}}$ Nonsignificant.

allowed to open. Samples were analyzed after anther dehiscence was verified using a hand lens. Pollen was removed from the anthers and placed on a slide. Viability was determined using the diaminobenzidine (DAB) test for peroxidase activity in pollen (Dafni et al., 2005). Rodriguez-Riano and Dafni (2000) compared the results of four vital dyes versus pollen germination results and illustrated the superiority of peroxidase tests over other commonly used vital dyes. The DAB test uses a dye that creates a color differential between viable and nonviable pollen. Four 100-pollen grain subsamples were analyzed from each plot using a compound microscope. A pollen grain was considered viable if it turned dark brown or black. All pollen samples were analyzed on the same day pollen was collected. It is important that watermelon pollen be thoroughly mixed with the dye on the slide to have adequate contact between the pollen grains and dye. If large clumps of pollen are not broken up, dye may not infiltrate the pollen and false-negatives may be observed. On each sample date, heatkilled pollen $\left(2 \mathrm{~h}\right.$ at $\left.80{ }^{\circ} \mathrm{C}\right)$ was analyzed to prevent false-positive readings. New dye was prepared for each sample date. Data were taken as percent viable pollen and square root transformations were performed. Analysis of variance (PROC GLM) and means separation (Duncan's multiple range test) were accomplished using SAS version 9.1 (SAS Institute, Cary, NC).

\section{Results}

There were no significant differences $(P$ $\leq 0.05$ ) in pollen viability observed among the pollenizer cultivars tested (Table 1$)$. In the spring trial, significant differences $(P \leq$ $0.05)$ in pollen viability were observed among sampling dates but not cultivars. There were no significant interactions observed between pollenizer cultivar and sampling date (Table 1).

Pollen samples taken on 31 May showed a greater average viability than samples taken on 24 May or 17 May (Table 2). Pollen viability on 31 May was $98.6 \%$, which was greater than $97.4 \%$ or $97.0 \%$ for 17 May and
24 May, respectively. The average pollen viability over all cultivars and all dates for spring and fall were $97.7 \%$ and $97.9 \%$, respectively. There was little variation within the data and the coefficients of variation were never higher than $0.84 \%$.

\section{Discussion}

The results of this study illustrate that there was no significant variation in pollen viability between the diploid pollenizer cultivars and that pollen viability changed very little during triploid fruit set. The results of this study are similar to Nepi and Pacini (1993) who studied 'Greyzini' (Cucurbita pepo L.) and found average pollen viability to be $\approx 92 \%$ at anthesis. The higher viability of pollen during one sampling date in the spring is more likely the result of environmental conditions and not cultivar characteristics. Nepi and Pacini (1993) also reported that decrease in pollen viability in 'Greyzini' was the result of dehydration of the pollen grain. High morning temperature or low relative humidity shortly after anthesis could decrease pollen viability. Freeman et al. (2007) observed that seedless watermelon yield was significantly lower when 'Companion' was used as a pollenizer versus 'Jenny' or 'SP-1'. The results of this study suggest that pollen viability was not a contributing factor in the varying degrees of performance of these pollenizers. Factors such as floral attractiveness to pollinators, availability and total production of staminate flowers, competitive growth, and quantity of pollen produced may be more important characteristics of pollenizers.

The small amount of variation in pollen viability between the cultivars tested suggests that there may be little variation within common diploid cultivars. Pollen viability appears to play no role in the performance of the pollenizers tested and may not be an important characteristic of pollenizer cultivars.

\section{Literature Cited}

Brevis, P.A., D.S. NeSmith, H.Y. Wetzstein, and D.B. Hausman. 2006. Production and viability of pollen and pollen-ovule ratios in four rabbiteye blueberry cultivars. J. Amer. Soc. Hort. Sci. 131:181-184.

Dafni, A., M. Neppi, and E. Pacini. 2005. Pollen and stigma biology, p. 83-147. In: A. Dafni, P.G. Kevan, and B. Husband (eds.). Practical pollination biology. Enviroquest, Cambridge, Canada.

Fiacchino, D.C. and S.A. Walters. 2003. Influence of diploid pollenizer frequencies on triploid watermelon quality and yields. HortTechnology 13:58-61.

Fortescue, J.A. and D.W. Turner. 2004. Pollen fertility in Musa: Viability in cultivars grown in southern Australia. Australian J. Agr. Res. 55:1085-1091.

Freeman, J.H., G.A. Miller, S.M. Olson, and W.M. Stall. 2007. Diploid watermelon pollenizer cultivars differ with respect to triploid watermelon yield. HortTechnology 17:518-522.

Lavi, U., S. Nachman, I. Barucis, D. Gaash, and A. Kadman. 1996. The effect of pollen donors and pollen viability on fruitlet drop in Macadamia integrifolia (Maiden \& Betche). Trop. Agr. 73:249-251.

Maynard, D.N. 1992. Growing seedless watermelon. Univ. Fla. Coop. Ext. Serv. Fact sheet HS687. 10 Dec. 2006. <http://edis.ifas.ufl.edu/ CV006>.

Maynard, D.N. and G.W. Elmstrom. 1992. Triploid watermelon production practices and varieties. Acta Hort. 318:169-173.

Nepi, M. and E. Pacini. 1993. Pollination, pollen viability and pistil receptivity in Cucurbita pepo. Ann. Bot. (Lond.) 72:527-536.

Nikkanen, T., T. Aronen, H. Häggman, and M Venäläinen. 2000. Variation in pollen viability among Picea abies genotypes-Potential for unequal paternal success. Theor. Appl. Genet. 101:511-518.

Olson, S.M., E.H. Simonne, W.M. Stall, P.D. Roberts, S.E. Webb, T.G. Taylor, and S.A. Smith. 2006. Cucurbit production in Florida, p. 191-237. In: S.M. Olson and E.H. Simonne (eds.). Vegetable production handbook for Florida. Univ. Fla. Coop. Ext. Serv. and Vance Publishing, Lenexa, KS.

Parzies, H.K., F. Schnaithmann, and H.H. Geiger 2005. Pollen viability of Hordeum spp. genotypes with different flowering characteristics. Euphytica 145:229-235.

Rhodes, B., K.B. Gruene, and W.M. Hood. 1997 Honey bees waste time on triploid male flowers. Cucurbit Genet. Coop. Rpt. 20:45.

Robinson, R.W. and D.S. Decker-Walters. 1997. Cucurbits. CAB Intl., Wallingford, UK.

Rodriguez-Riano, T. and A. Dafni. 2000. A new procedure to assess pollen viability. Sex. Plant Reprod. 12:241-244.

Stanghellini, M.S. and J.R. Schultheis. 2005 Genotypic variability in staminate flower and pollen grain production of diploid watermelons. HortScience 40:752-755.

U.S. Department of Agriculture. 2006. National watermelon report. U.S. Dept. Agr. Agricultural Marketing Service. 22 Jan. 2007. <http://www. ams.usda.gov>. Thomasville, GA.

Vithanage, V. 1991. Effect of different pollen parents on seediness and quality of 'Ellendale' tangor. Scientia Hort. 48:253-260.

Wallace, H.M. and L.S. Lee. 1999. Pollen source, fruit set and xenia in mandarins. J. Hort. Sci. Biotechnol. 74:82-86. 